\title{
Quantifying measures to limit wind-driven resuspension of sediments for improvement of the ecological quality in some shallow Dutch lakes
}

\author{
W. E. Penning $\cdot$ M. Genseberger $\cdot$ \\ R. E. Uittenbogaard $\cdot$ J. C. Cornelisse
}

Received: 19 July 2011 / Accepted: 5 February 2012/Published online: 21 February 2012

(C) The Author(s) 2012. This article is published with open access at Springerlink.com

\begin{abstract}
Although phosphorus loadings are considered the main pressure for most shallow lakes, winddriven resuspension can cause additional problems for these aquatic ecosystems. We quantified the potential effectiveness of measures to reduce the contribution of resuspended sediments, resulting from wind action, to the overall light attenuation for three comparable shallow peat lakes with poor ecological status in the Netherlands: Loosdrecht, Nieuwkoop, and Reeuwijk (1.8-2.7 m depth, 1.6-2.5 km fetch). These measures are: 1 . wave reducing barriers, 2 . water level fluctuations, 3. capping of the sediment with sand, and 4 . combinations of above. Critical shear stress of the sediments for resuspension $\left(V_{\text {crit }}\right)$, size distribution, and optical properties of the suspended material were quantified in the field (June 2009) and laboratory. Water quality monitoring data (2002-2009) showed that light attenuation by organic suspended matter in all lakes is high. Spatial modeling of the impact of
\end{abstract}

Guest editors: Zhengwen Liu, Bo-Ping Han \& Ramesh D. Gulati / Conservation, management and restoration of shallow lake ecosystems facing multiple stressors

W. E. Penning $(\bowtie) \cdot$ M. Genseberger ·

R. E. Uittenbogaard · J. C. Cornelisse

Deltares, P.O. Box 177, 2600 MH Delft, The Netherlands

e-mail: Ellis.Penning@deltares.nl

W. E. Penning

Netherlands Institute of Ecology, Droevendaalsesteeg 10, 6708 PB Wageningen, The Netherlands these measures showed that in Lake Loosdrecht limiting wave action can have significant effects (reductions from $6 \%$ exceedance to $2 \%$ exceedance of $V_{\text {crit }}$ ), whereas in Lake Nieuwkoop and Lake Reeuwijk this is less effective. The depth distribution and shape of Lake Nieuwkoop and Lake Reeuwijk limit the role of wind-driven resuspension in the total suspended matter concentration. Although the lakes are similar in general appearance (origin, size, and depth range) measures suitable to improve their ecological status differ. This calls for care when defining the programme of measures to improve the ecological status of a specific lake based on experience from other lakes.

Keywords Water Framework Directive (WFD) measures - Ecological status - Transparency · Suspended matter · Wind-driven resuspension

\section{Introduction}

The Water Framework Directive (WFD) (EU, 2000) requires all waters in European Member States to be clean and healthy and reach 'good ecological status' by 2027 . Water bodies with a bad, poor, or moderate status need to improve to good status by implementing measures. These measures must counterbalance the effects of negative environmental pressures on the ecosystem. Although phosphorus loadings are considered to be the main pressure for most aquatic systems 
(Moss, 1998; Brönmark \& Hansson, 2002), the turbidity caused by dead organic and inorganic suspended matter (next to the turbidity caused by living algae) can limit light availability with increasing depth in aquatic ecosystems and therefore constrain the (re-establishment of macrophytes (Van Duin et al., 2001; Scheffer, 2001; James et al., 2004). Nutrient load reducing measures are implemented to limit algal growth and turbidity caused by them. Additional measures to reduce turbidity caused by non-algal suspended matter will help improve the light conditions to a point that macrophytes can re-establish and thereby improve the overall ecological status of the water body. For considering measures to improve the underwater light climate in a certain lake, water managers often assess those that proved effective in lakes of the same lake type (e.g., Søndergaard et al., 2007; Jeppesen et al., 2007). These measures can be classified in three sequential pathways to improve the light climate:

(i) Chemical pathway: Nutrient load reduction to attain a maximally acceptable critical nutrient load (mg P m ${ }^{-2}$ year $^{-1}$, Janse et al., 2008);

(ii) Mechanical pathway: Hydromorphological measures to limit resuspension of sediment via, e.g., deepening (Penning et al., 2010), wind reducing barriers, sand capping of the sediment, and water level fluctuations (Van Geest et al., 2005), and alterations to the shoreline profile (Sollie et al., 2008);

(iii) Biological pathway: biomanipulation measures in which top-down control of the foodweb is influenced via the active removal of the surplus of benthivorous white fish, when these dominate the foodweb (e.g., Meijer et al., 1999, Søndergaard et al., 2007). Only after measures from the chemical and mechanical pathway have been carried out, biomanipulation functions as a 'shock-treatment' (Søndergaard et al., 2007; Gulati et al., 2008).

Lake typology as suggested by the WFD is often used to group and compare lakes that are similar in, e.g., depth, size, alkalinity, and color. Also, lakes of the same type are often considered to benefit in a similar way from the same types of measures. In the Netherlands, one such lake type is the "moderately large shallow lakes with high alkalinity and a peat soil" (0.5-100 km²) (STOWA, 2007). These lakes are man-made excavations of the peat soil (partially) filled with external water sources of high alkalinity such as inlets from the river Rhine. Many of the lakes in this category have problems related to their high turbidity and have lost their well-developed macrophyte communities due to eutrophication and strict management of water level and water sources. Wind- and wavedriven erosion of the sediment in these shallow lakes causes an additional source of suspended particles in the water column that can persist for a prolonged period of time especially when the fall velocity (sinking rate) of these particles is limited (Van Duin et al., 2001; Winterwerp \& Van Kesteren, 2004). Also, benthivorous fish feeding activity and recreational motor boating will contribute to the erosion and soil stability, especially in summer time (Scheffer et al., 2003). The resulting turbidity hampers the (re-)establishment of a resilient macrophyte community (James \& Barko, 1994; Best et al., 2008) and thereby limits the functioning of the lake ecosystem as a whole. For Lake Loosdrecht, which is one of the lakes in this lake type, the past studies indicate that wind-driven resuspension of sediments contributes significantly to the overall turbidity (Gons et al., 1986; Van Liere, 1986; Penning et al., 2010). We hypothesized that this process of wind-driven resuspension also applies to two other lakes of the same lake type: Lake Nieuwkoop and Lake Reeuwijk. For these two last lakes, much less information is available and we expected that given their similarity to Lake Loosdrecht they also experience the wind-driven resuspension and resulting turbidity problems.

In this study we assessed the contribution of different types of suspended particles to the light attenuation in these three shallow peat lakes (Lake Loosdrecht, Lake Nieuwkoop, and Lake Reeuwijk) and quantified the effectiveness of potential measures (wave reducing barriers, sand capping of the sediment, and water level fluctuation) to limit wind-driven resuspension of sediment in these lakes to improve the light climate using mathematical modeling.

\section{Lake description}

Lake Loosdrecht, Lake Nieuwkoop, and Lake Reeuwijk, are located in the western part of the Netherlands (Fig. 1) and they all have similar history of eutrophication over time (Van der Does et al., 1992, 
Fig. 1 An outline sketch of the central part of Netherlands showing the lakes in insets (1 Lake Reeuwijk, 2 Nieuwkoop, and 3 Loosdrecht). Dotted lines indicate the sections of the lake systems used in this study

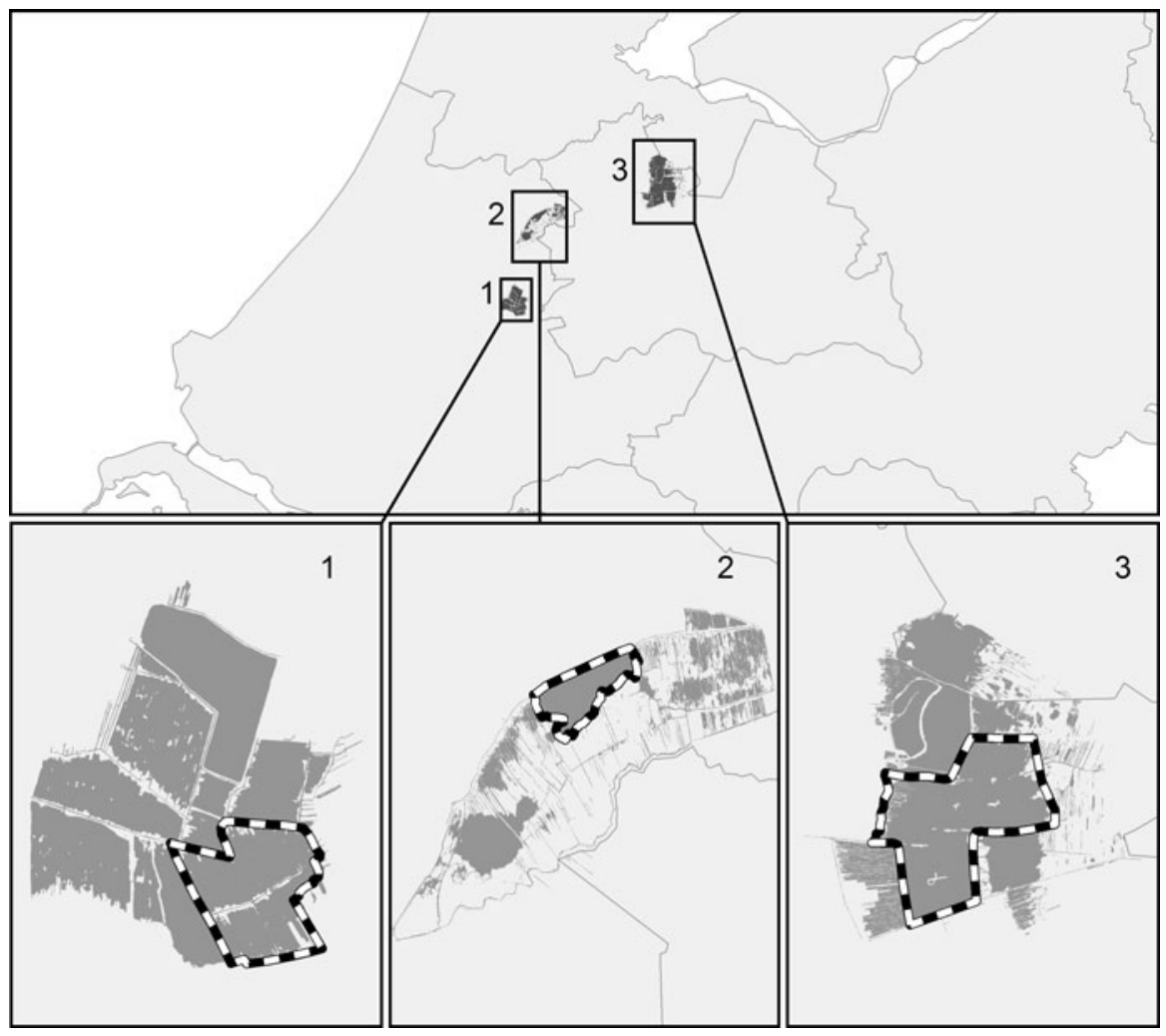

Gulati \& Van Donk, 2002). The names we use in this study refer to the overall greater areas where the lakes are located. For this study we used subsections of the lake systems: in Loosdrecht we use the main lake (plas 1-5), in Nieuwkoop the most northern large lake (Nieuwkoop-Noord), in Reeuwijk the two linked south-eastern lakes (Nieuwenbroek and Kalverbroek). The lakes originated from peat harvesting starting as early as the fifteenth century (Bakker et al., 1976). The waters were reported to be clear with charophytedominated macrophyte communities up to 1960 s, i.e., when eutrophication started to become a problem (Leentvaart \& Mörzer Bruijns, 1962; Best et al., 1984; Van Dam \& Mertens, 1993; Van Dam \& Frinking, 1997). The lakes are interconnected with the surrounding polder systems (predominantly pastures and grazing fields and natural reserves) and have a layer of organic mud deposit on the bottom, with a compact peat layer below. Although the mud layer thickness in all lakes is on average $0.2 \mathrm{~m}$ thick, local variations per lake make that in some sheltered areas of the lakes the thickness can reach up to $0.7 \mathrm{~m}$. The average depth of the lakes ranges from $1.8 \mathrm{~m}$ (Lake Loosdrecht) to
$2.7 \mathrm{~m}$ (Lake Nieuwkoop) and fetch length is on average between $1.6 \mathrm{~km}$ (Lake Reeuwijk) and $2.6 \mathrm{~km}$ (Lake Loosdrecht) with maximum fetch lengths up to $3.6 \mathrm{~km}$ in Lake Loosdrecht for some locations within the lake (Table 1). Predominant wind direction in the Netherlands is from the south west and for Lake Loosdrecht the relationship between winds and suspended matter were already reported by Gons et al. (1986). All lakes experience high anthropogenic pressure, mainly through recreational boating and agricultural activity in the surroundings. Nutrient loading to the lakes comes both from point sources (mainly known water inlet points from surrounding polders and canals) and non-point sources from polder areas within the study area. Although nutrient levels have reduced since the 1980 s to (more or less) best capability by the responsible water management authorities, the lakes have remained remarkably turbid and macrophytes have not re-established up to this date. Lake Reeuwijk is least transparent of the lakes with an average light attenuation coefficient of $4.4 \mathrm{~m}^{-1}$ in summer time (based on data from 2009), while Lake Nieuwkoop is clearest with light 
Table 1 General characteristics of the lakes Reeuwijk, Nieuwkoop, and Loosdrecht (with minimum and maximum values between brackets)

\begin{tabular}{llll}
\hline & Reeuwijk & Nieuwkoop & Loosdrecht \\
\hline Depth $z(\mathrm{~m})$ & $2.0(1.4-2.2)$ & $2.7(1.8-3.3)$ & $1.8(1.4-2.7)$ \\
Mud layer thickness $(\mathrm{m})$ & $0.2(0.1-0.7)$ & $0.2(0.1-0.7)$ & $0.1(0-0.24)$ \\
Fetch $(\mathrm{km}$ for SW wind) & 1.6 & 2.1 & $2.5(3.6 \mathrm{max})$ \\
Light attenuation $k\left(\mathrm{~m}^{-1}\right)$ & 4.4 & 2.0 & 2.3 \\
Area $\left(\mathrm{km}^{2}\right)$ & 3.5 & 4.5 & 10 \\
Dominant wind direction & $\mathrm{SW}$ & $\mathrm{SW}$ & $\mathrm{SW}$ \\
\hline
\end{tabular}

attenuation coefficients of $2.0 \mathrm{~m}^{-1}$ in summer time (based on data from 2009) (Table 1).

\section{Methods}

We analyzed the contributions of different substances in the suspended material to the overall light attenuation and for samples taken from the field we measured various characteristics of the suspended matter and the top sediment layers (specific dry weight, particle size distribution, critical flow speed for erosion, and light attenuation by the suspended particles). This information was linked to spatial analyses of the potential for wind-driven erosion of the bed. The effects of mechanical measures such as wave reducing barriers, sand capping, or water level fluctuations, or combinations thereof were further quantified for those situations where wind-driven erosion was a factor of concern using mathematical modeling.

Analysis of the underwater light climate

We used a minimum of $4 \%$ light of the surface light reaching the lake bottom as an average proxy for the amount of light needed for germination in the field, following the methods used by Kenworthy \& Fonseca (1996), Kemp et al. (2004), Dobberfuhl (2007), and unpublished data on the relation between seed bank density and light needed for germination by a variety of species by Van den Berg \& Delauney, rather than an absolute quantity of light (expressed in $\mu$ mol photons $\mathrm{m}^{-2} \mathrm{~s}^{-1}$ ) to account for the fact in the field the fluctuation in light intensity is high depending on meteorological conditions and time of the year. In this method we used the Lambert-Beer equation for light attenuation
$I_{(z)}=I_{(0)} \mathrm{e}^{-k z}$

in which $I_{(z)}=$ radiation at depth $z\left(\mathrm{~W} \mathrm{~m}^{-2}\right)$, $I_{(0)}=$ surface radiation $\left(\mathrm{W} \mathrm{m}^{-2}\right), k=$ attenuation coefficient $\left(\mathrm{m}^{-1}\right), z=$ depth $(\mathrm{m})$. We defined the relation between this $4 \%$ light requirement and the needed light attenuation coefficient $k$ combined with the maximum depth $z$ at which this percentage of incoming light is still available, thereby representing a maximum depth of colonization by macrophytes. By quantifying the combined $k z$ we established a reference value below which sufficient light is available for potential macrophyte germination and growth. With $I_{(z)} / I_{(0)}=4 \%$ this combined $k z$ is 3.2 as the maximum value for potential macrophyte germination. By quantifying the relative contribution of different substances to the total light attenuation we identified which potential pathways to reduce the $k z$ can be followed: i.e., chemical pathway measures affect the contribution of living and decaying algal biomass to light attenuation or mechanical pathway measures that affect the contribution of refractory detritus and inorganic matter to light attenuation (Fig. 2).

In order to assess the contributions of the various suspended materials to light attenuation within PAR (400-700 nm) we used long-term monitoring data on chlorophyll $a$, total suspended matter, humic acids (if available), inorganic matter, and light attenuation coefficients provided by the regional waterboards Waternet for Loosdrecht and Hoogheemraadschap van Rijnland for Nieuwkoop and Reeuwijk. We used these monitoring data as input for the dedicated light attenuation model "UITZICHT" (Buiteveld, 1995) to assess the contribution of various substances to light attenuation within PAR (400-700 nm). The results of this calculation (light attenuation per contribution substance) were related to the measured total light attenuation coefficients for validation of the results. 


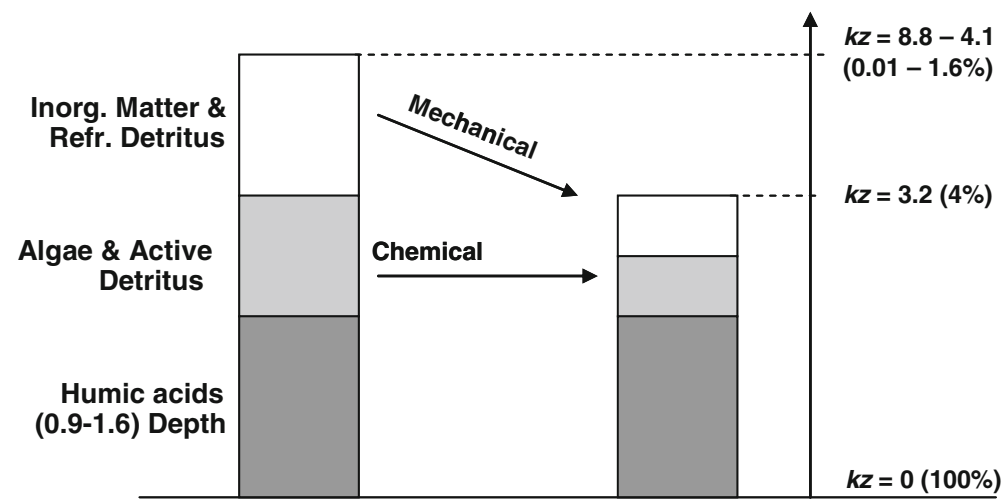

Fig. 2 Conceptual relationship between light attenuation components (inorganic matter and refractory detritus, algae and active detritus, humic acids) with depth and the total combined light attenuation and depth value ' $k z$ ', with $k z$ values determined and used in this study. Height of the column represents height of $k z$ value. Mechanical pathway measures influence the inorganic matter and refractory detritus component; chemical pathway measures influence the algae and active detritus component contributing to the overall light attenuation and therefore to the $k z$ (arrows). When the $k z$ value is 3.2 this equals $4 \%$ light reaching the bottom of the lake that is taken as a minimum criterion for macrophyte germination
Fig. 3 Set up of the lab experiments to measure susceptibility of lake sediment to flow velocities at which the critical shear stresses is exceeded ( $\left.V_{\text {crit }}\right)$ using a Vane propeller and extraction of the suspension using a small pump to transport and measure optical characteristics of the resuspended material (OSLIM1 and OSLIM2) and its particle size distribution (Malvern)

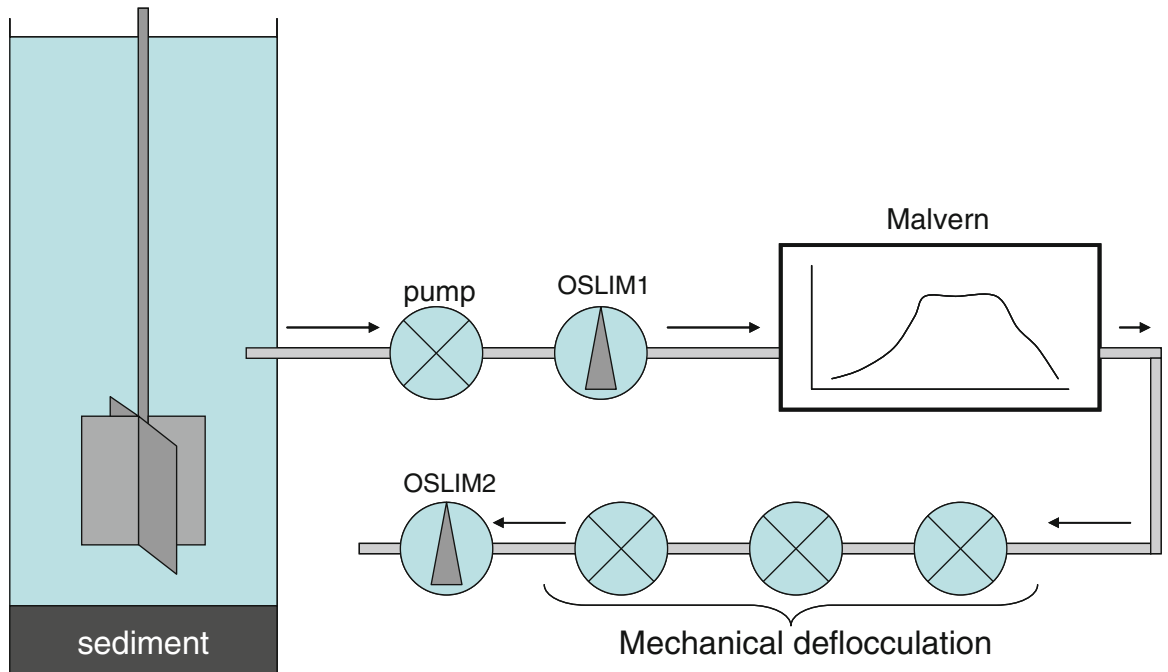

undisturbed, i.e., an intact sediment core was taken by pushing a Plexiglas tube $(\varnothing 0.06 \mathrm{~m})$ down into the sediment that was then sealed on both ends. All cores were transported in vertical position to the lab for further analysis, avoiding disturbance by shaking. Before analysis, the cores were stored at $12^{\circ} \mathrm{C}$ in the dark.

\section{Laboratory measurements}

Using the undisturbed sediment cores from the field we measured critical shear stress, specific dry weight of the resuspended material, and particle size distribution and light attenuation properties of the 
resuspended particles, both in flocculated and deflocculated state (Fig. 3). We placed a Vane propeller in the undisturbed water column $15 \mathrm{~mm}$ above the sediment in the cores (layer of $\sim 15 \mathrm{~cm}$ thickness) and applied stepwise increased settings of Vane propeller speed to the sediment to define flow velocities at which the critical shear stresses $\left(V_{\text {crit }}\right)$ were exceeded. The Vane is a propeller connected to a small motor that can be adjusted to move the propeller with a known revolutions per minute (rpm). The relation between the propeller speed and bottom shear stress values is established and calibrated using sand samples with known grain-size and compared to Shields values for shear stress (Shields, 1936). The method is one of many used in studies to measure properties of cohesive and non-cohesive soils in response to applied forces (viz. EROMES Nöther 1989, Cornelisse et al., 1993). Next to first series of increasing settings, we used two settings, each of $20 \mathrm{~min}$, to assess the stability of the sediment and amount of sediment that would resuspend under such settings: a first setting of 30 revolutions per min (rpm) of the Vane, and a second setting of $60 \mathrm{rpm}$. The rotational speed of the Vane propeller was translated into flow velocity (50 and $140 \mathrm{~mm} \mathrm{~s}^{-1}$ resp. for the settings 1 and 2) and typical wind speeds that would cause such bottom flows at the depths typical per lake are $\left(\sim 5\right.$ and $8 \mathrm{~m} \mathrm{~s}^{-1}$, comparable with $\sim 3$ and $\sim 5$ on the Beaufort wind scale (Bft.), respectively). During the experiments, water was gently extracted by suction from the water column in the core and transported via silicon tubes to a first OSLIM meter (Optical Silt meter, Deltares, The Netherlands), numbered OSLIM1, to measure light attenuation of the eroded material with flocculated material present. The OSLIM is an optical inline turbidity meter designed to measure concentrations of suspended particles in relatively small quantities of sampling liquid that is subtracted from the experiment. The measuring principle is based on the attenuation of the intensity of a light beam (LED) through absorption and reflection of the light by particles in the liquid that is pumped through the flow cell placed between a nearinfrared LED and a photo diode within the probe (WL/ Deltares, 2001). After this first OSLIM measurement, the sample flowed to a Malvern Mastersizer2000 (Malvern Instruments Ltd.) which uses non-intrusive laser diffraction to measure particle size distribution of the eroded flocs that are passed through a focused laser beam. The particles scatter the laser beam light at an angle that is inversely proportional to their size. The angular intensity of the scattered light is then measured by a series of photosensitive detectors. After the sample has passed through the Malvern, the particles were pumped over a series of pumps to mechanically deflocculate potential large flocs. The resulting sample was measured on a second OSLIM (numbered OSLIM2) to measure the individual particles rather than the flocs. The OSLIM measurements are expressed as Formazine Turbidity Units and are determined at $880 \mathrm{~nm}$, rather then at the PAR spectrum (400-700 nm) that the Li-Cor underwater light meter records in the field. In order to relate the readings from the OSLIM with the field data on light attenuation in the lakes, OSLIM output was calibrated using formazine in known concentrations to establish a correlation of the FTUs with a comparable value of light attenuation in PAR range. The particle size distribution measurements were compared with previous measurements on light attenuation per size class for suspended matter in Nieuwkoop (Sloot, 1995; Table 2). Dry weight of the suspended matter was determined by drying for $24 \mathrm{~h}$ the filtered material in an oven at $105^{\circ} \mathrm{C}$. All measurements were replicated $(3 \times)$. The measured $V_{\text {crit }}$ values for erosion were used as input for the spatial modeling analyses on windwave-driven resuspension in the lakes.

\section{Wind-driven erosion exceedance}

Spatial analysis of wind-wave-driven erosion was carried out using the validated bathymetric maps as model input (interpolated grid). Data on hourly values of wind force and wind direction, as measured at a reference height of $10 \mathrm{~m}$ at Schiphol Airport were provided by the Royal Netherlands Meteorological Institute (KNMI) from 1 January 2005 to 1 April 2005. These were used as direct input to calculate the orbital velocity per grid cell per time step with the formulations of Hurdle \& Stive (1989) and related to the lab

Table 2 Values of the combined averaged light attenuation $k$ and averaged depth $z(k z)$ and flow velocities at which the critical shear stresses is exceeded $\left(V_{\text {crit }} \mathrm{m} \mathrm{s}^{-1}\right)$ at which bed erosion starts, measured using the Vane propeller

\begin{tabular}{llll}
\hline & Reeuwijk & Nieuwkoop & Loosdrecht \\
\hline$k z(-)$ & 8.8 & 5.4 & 4.1 \\
$V_{\text {crit }}\left(\mathrm{m} \mathrm{s}^{-1}\right)$ & 0.041 & 0.063 & 0.055 \\
\hline
\end{tabular}


measurements on $V_{\text {crit }}$ per lake. The number of days that a grid cell exceeded these measured $V_{\text {crit }}$ values due to wind-driven wave action was expressed as a percentage per period and this percentage was plotted on spatial maps to allow for identification of hotspots of erosive activity. For hotspot areas in Lake Loosdrecht additional spatial analyses included combinations of various wind-driven erosion reducing measures, using local wind data from 1 January 2005 to 1 April 2007.

\section{Results}

Light analysis

Given the differences in depth, the $k z$ value 8.8 for Reeuwijk (mean depth $2.7 \mathrm{~m}$ ) is much higher than $\mathrm{kz}$ value of 4.1 for Loosdrecht (mean depth $1.8 \mathrm{~m}$ ) and the $k z$ value of 5.4 Nieuwkoop (mean depth 2.7) (Table 2). Therefore, it indicates that not sufficient light reaches the bottom of the lake. The $k z$ for Lake Loosdrecht (4.1) is closest to the value of 3.2 needed to have sufficient light at the bottom for potentially successful macrophyte germination.

The suspended organic matter, which is the major contributor to the light attenuation, will determine light availability at the different depths in all three lakes (Fig. 4). Previous studies on C:N ratios of the suspended matter for Lake Loosdrecht showed that $\sim 50 \%$ of the organic suspended matter has a peat origin; the other $50 \%$ consists of labile, decomposing algae (Medusa, 2007, see also Penning et al., 2010). For the lakes Reeuwijk and Nieuwkoop such studies have not been carried out so far. Humic acids are a significant contributor to the total light attenuation in all three lakes given presence of peat soil in the area (Laanen, 2007). In all lakes inorganic suspended material is almost absent. The calculations of the overall light attenuation are comparable to the measured data for all three lakes.

\section{Laboratory experiments}

Critical shear stress expressed as $V_{\text {crit }}$ is significantly higher in Lake Nieuwkoop than in Lake Loosdrecht and Lake Reeuwijk (Fig. 5; Table 2). At the low setting of $30 \mathrm{rpm}\left(63 \mathrm{~mm} \mathrm{~s}^{-1}, \sim 3 \mathrm{Bft}\right.$ wind force) the measured turbidity values with both OSLIM1 and
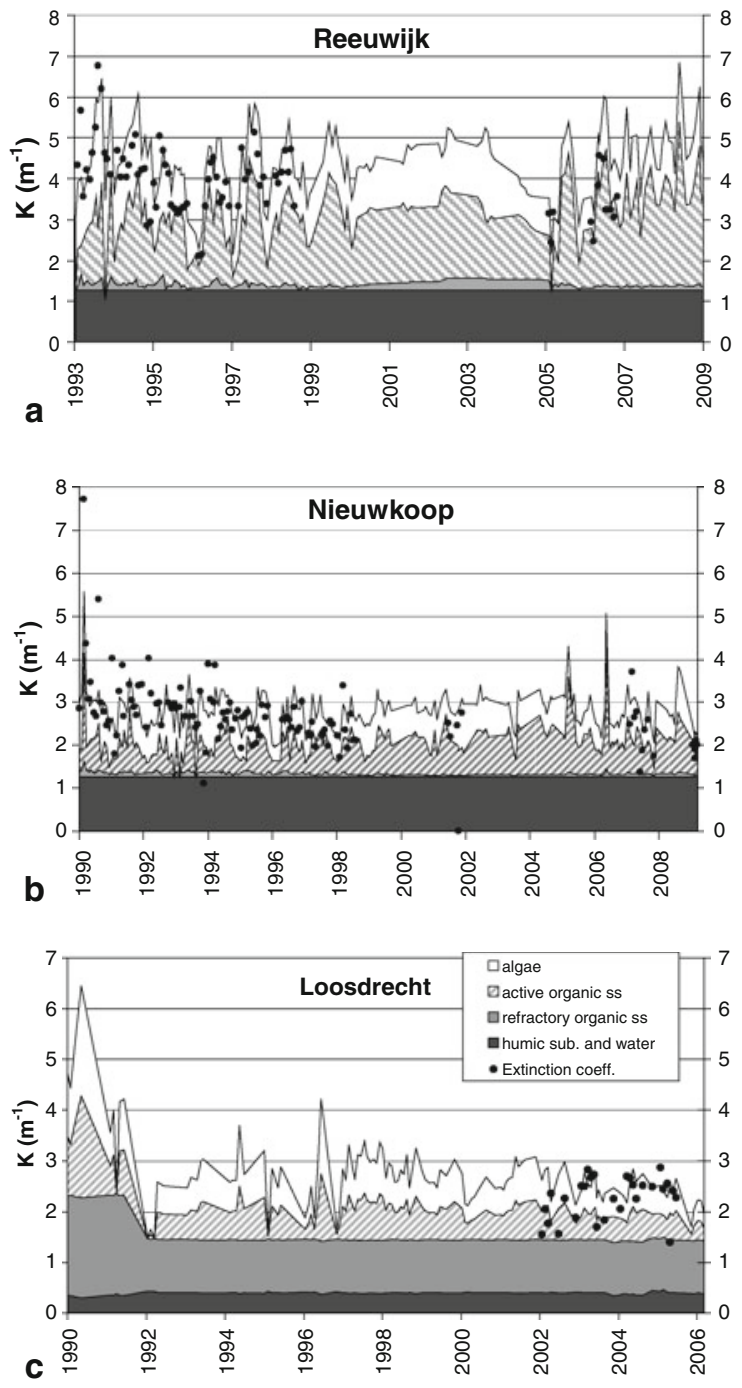

Fig. 4 Contributions of individual substances (humic acids, inorganic suspended matter, organic suspended matter, and living algae) to the overall light attenuation coefficient for the lakes Reeuwijk (a), Nieuwkoop (b), and Loosdrecht (c) from 1990 to 2008 based on calculations using UITZICHT (Buiteveld, $1995)$ in relation to measured total light attenuation (dots)

OSLIM2 were low. Only at the high setting of $60 \mathrm{rpm}$ $\left(126 \mathrm{~mm} \mathrm{~s}^{-1}, \sim 5 \mathrm{Bft}\right)$ the sediment starts eroding, indicating that the bottom of Lake Nieuwkoop seems more consolidated than those of other the two lakes, where it is quickly eroded. After an initial rapid increase in turbidity measured by the OSLIM1 and OSLIM2, the turbidity reaches a stable higher value that increases further when a higher erosive setting is started. Again, after ca. $15 \mathrm{~min}$, the turbidity becomes stable at a higher concentration and resulting erosion, 

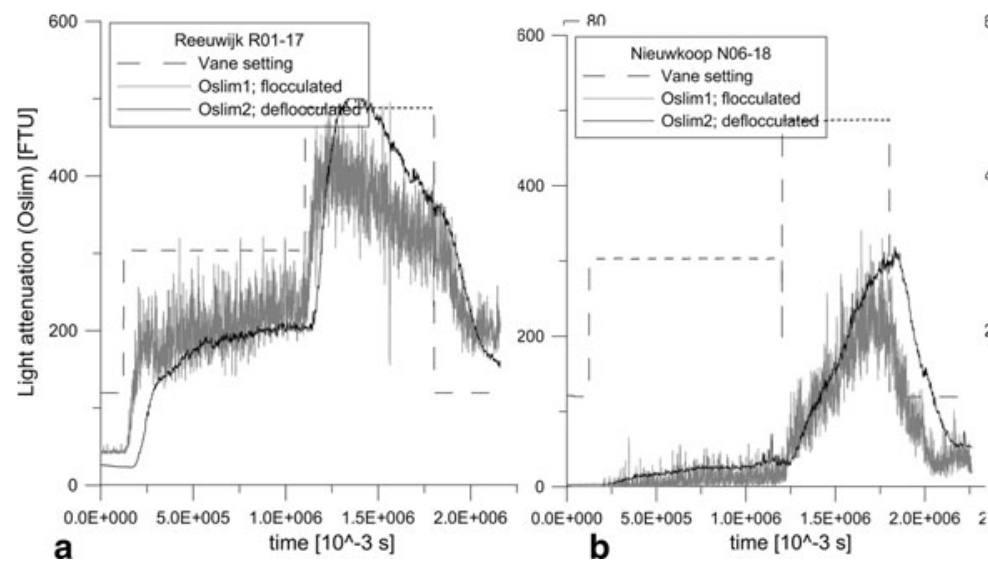

b

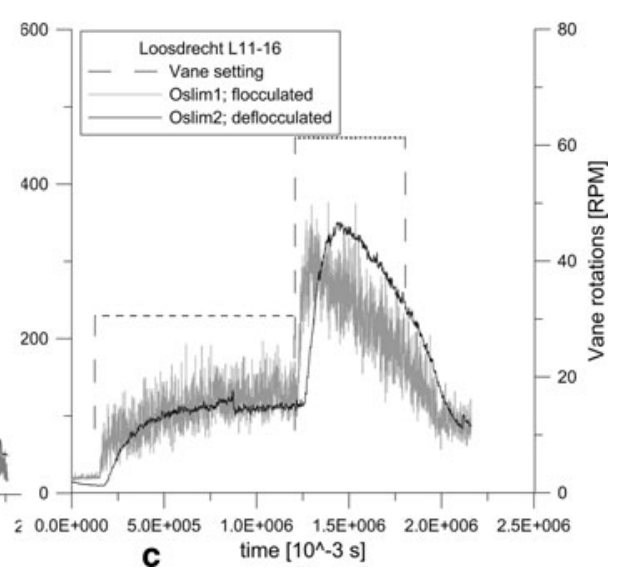

C
Fig. 5 Turbidity measurements using the OSLIM1 (intact flocs) and OSLIM2 (after mechanical breaking of flocs) of the water extracted from the water column during the sediment

Table 3 Results (average \pm standard error) of the OSLIM measurements for the three study lakes in both Formazine Turbidity Units measured directly by the OSLIM (FTU at $800 \mathrm{~nm}$ ) during the experiments, translated FTU to a $\mathrm{L} \mathrm{mg}^{-1}$ erosion experiments for Lake Reeuwijk (a), Lake Nieuwkoop (b), and Lake Loosdrecht (c). The horizontal lines indicate the Vane rotational speed (rpm)

\begin{tabular}{|c|c|c|c|c|c|c|c|}
\hline \multirow[t]{2}{*}{ Lakes } & \multirow[t]{2}{*}{ Unit } & \multicolumn{2}{|l|}{ Reeuwijk } & \multicolumn{2}{|c|}{ Nieuwkoop } & \multicolumn{2}{|c|}{ Loosdrecht } \\
\hline & & Average & SE & Average & SE & Average & SE \\
\hline Dry weight & $\mathrm{mg} \mathrm{L}^{-1}$ & 283.5 & 58.9 & 338.7 & 33.0 & 407.0 & 54.6 \\
\hline OSLIM1 & FTU & 230.7 & 54.9 & 112.7 & 9.9 & 143.7 & 50.3 \\
\hline OSLIM2 & FTU & 275.0 & 76.5 & 139.3 & 5.5 & 175.0 & 61.7 \\
\hline OSLIM1 & FTU $\mathrm{L} \mathrm{mg}^{-1}$ & 0.83 & 0.16 & 0.35 & 0.02 & 0.39 & 0.09 \\
\hline OSLIM2 & FTU $\mathrm{L} \mathrm{mg}^{-1}$ & 0.96 & 0.19 & 0.42 & 0.05 & 0.45 & 0.16 \\
\hline OSLIM1 & $\mathrm{m}^{-1} \mathrm{~L} \mathrm{mg}^{-1}$ & 0.070 & & 0.029 & & 0.033 & \\
\hline OSLIM2 & $\mathrm{m}^{-1} \mathrm{~L} \mathrm{mg}^{-1}$ & 0.081 & & 0.035 & & 0.038 & \\
\hline
\end{tabular}

Calibration for this experiment: $100 \mathrm{FTU}=8.5 \mathrm{~m}^{-1}$

implying that the amount of material resuspended also depends on the thickness of an erodible layer.

The average turbidity values measured with the OSLIM during the experiments were recalculated to values per mg dry weight (Table 3 ). Although the total dry weight of the suspended matter of $283 \mathrm{mg} \mathrm{L}^{-1}$ DW measured for Reeuwijk is the lowest dry weight value for the three lakes, the contributing light attenuation is highest $\left(0.08 \mathrm{~m}^{-1} \mathrm{~L} \mathrm{mg}^{-1}\right.$ for Reeuwijk, compared to 0.035 for Loosdrecht and Nieuwkoop). The Malvern measurements show that the sediment in Lake Nieuwkoop and Lake Loosdrecht contain a relatively high percentage of larger particles with diameter of flocs around $1 \mathrm{~mm}$, while these flocs are less prominent in Lake Reeuwijk. In Lake Reeuwijk and conversed to a light attenuation in PAR 400-700 $\left(\mathrm{m}^{-1}\right)$ per $\mathrm{L} \mathrm{mg}^{-1}$ on the suspended matter obtained from the vane experiments compared to the total overall dry weight of the suspended matter
$\mathrm{D}_{50}$ is approximately $0.1 \mathrm{~mm}$, while in Lake Nieuwkoop and Loosdrecht $D_{50}$ is approximately $0.2 \mathrm{~mm}$. This also helps to explain the measured light attenuation per dry weight suspended matter that is high for Lake Reeuwijk in comparison with the measurements in Lake Nieuwkoop and Lake Loosdrecht. For this, we compared our results to measurements of Sloot (1995; Table 4) on suspended matter from lake Nieuwkoop, that focus on the role of particle size on light attenuation. The measurements of Sloot (1995) show that the contribution of very small particles, with a low fall velocity, to the overall attenuation is high $(21 \%)$. Based on this, and on the laser diffraction measurements using the Malvern to quantify particle size distribution we conclude that the average size of 
Table 4 Main

characteristics of the five size fractions of suspended sediment as measured for samples from Lake

Nieuwkoop

Source: Sloot (1995)

\begin{tabular}{|c|c|c|c|c|}
\hline \multirow[t]{2}{*}{ Fraction } & \multirow{2}{*}{$\begin{array}{l}\text { Fall velocity } \\
\left(\mathrm{mm} \mathrm{s}^{-1}\right)\end{array}$} & \multirow{2}{*}{$\begin{array}{l}\text { Specific attenuation } \\
(\mathrm{PAR})\left(\mathrm{m}^{-1} \mathrm{~L} \mathrm{mg}^{-1}\right)\end{array}$} & \multicolumn{2}{|c|}{ Contribution (\%) } \\
\hline & & & $\begin{array}{l}\text { Total } \\
\text { attenuation }\end{array}$ & $\begin{array}{l}\text { Sedimentation } \\
\text { flux }\end{array}$ \\
\hline 1 & $<0.1$ & 0.080 & 21 & 2 \\
\hline 2 & $0.1-0.6$ & 0.036 & 2.4 & 4 \\
\hline 3 & $0.6-1.0$ & 0.051 & 0.4 & 4 \\
\hline 4 & $1.0-5.0$ & 0.028 & 0.3 & 8 \\
\hline 5 & $>5.0$ & 0.015 & 0.1 & 82 \\
\hline
\end{tabular}

Nieuwkoop (Noordeinderplas) for fictive uniform depth of $1.70 \mathrm{~m}$

Loosdrecht $\left(1^{\text {st }}, 2^{\text {nd }}, 3^{\text {rd }}, 4^{\text {th }}\right.$, and $5^{\text {th }}$ lake $)$

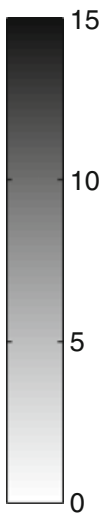

Nieuwkoop (Noordeinderplas) with actual depth

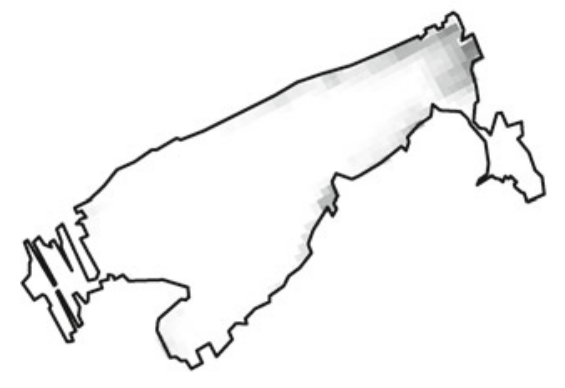

C

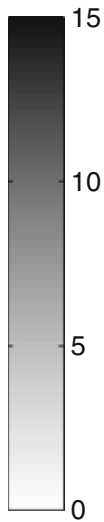

Fig. 6 Percentage exceedance of flow velocities at which the critical shear stresses is exceeded $\left(V_{\text {crit }}\right)$ based on meteorological data from 1 January 2005 to 1 April 2005 for Lake Loosdrecht

suspended particles in Reeuwijk is smaller than in Nieuwkoop and Loosdrecht. The average attenuation characteristics of the suspended matter of Lake Nieuwkoop and Lake Loosdrecht are similar to each other (ca. $0.03 \mathrm{~m}^{-1} \mathrm{~L} \mathrm{mg}^{-1}$ dry weight).

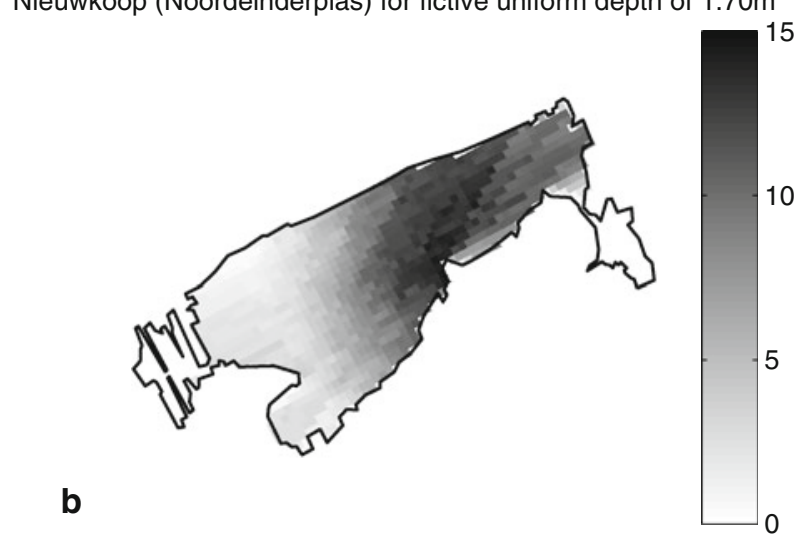

b

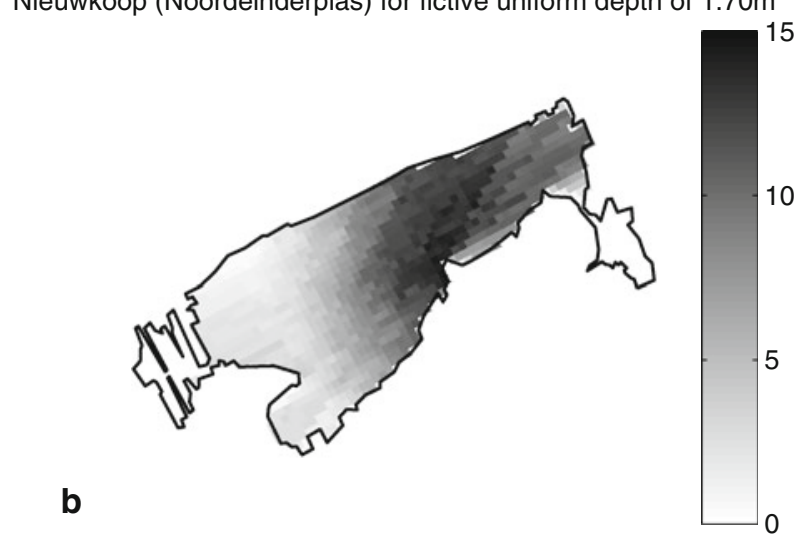

Reeuwijk (Nieuwenbroek/Kalverbroek)

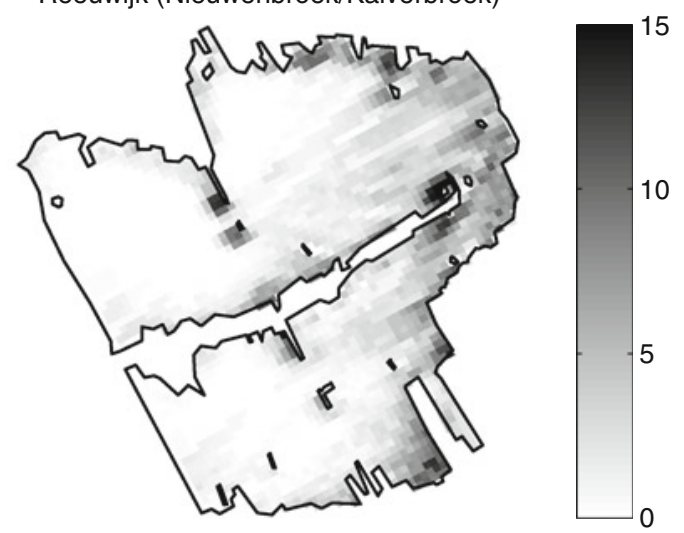

(a); Lake Nieuwkoop with the fictive depth of $1.7 \mathrm{~m}$ (comparable to the depth of Lake Loosdrecht, b); Lake Nieuwkoop with its' actual depth (c); and Lake Reeuwijk (d)

Spatial modeling analysis

Wind-driven resuspension of suspended matter occurs often in Lake Loosdrecht (Fig. 6a) and $V_{\text {crit }}$ is exceeded about $6 \%$ of the studied period (i.e., 
comparable to $500 \mathrm{~h}$ per year, note that the exceedance frequency is computed by dividing the number of exceedances with the total amount of hourly observations). The limited fall velocity of the fine suspended organic matter implies that most of the organic material is constantly prone to settling and erosion (Penning et al., 2010). Had Lake Nieuwkoop the same average depth as Lake Loosdrecht $(1.8 \mathrm{~m})$, than it would have been very prone to resuspension (Fig. 6b). However, being $2.7 \mathrm{~m}$ deep-rather than $1.8 \mathrm{~m}$ deep-Lake Nieuwkoop experiences only $2 \%$ of exceedance of $V_{\text {crit }}$ (Fig. 6c). A similar result was obtained for Lake Reeuwijk, that has less wind-driven resuspension with an average fetch in south western direction of 1.6 versus $2.6 \mathrm{~km}$ fetch of Loosdrecht (but about the same depth as Lake Loosdrecht) resulting in $2 \%$ exceedance. This is due to the topography of the lake: a few small wind reducing islands and barriers reduce the locations where wind fetch combined with depth result in such high waves that the orbital motion created by them exceeds $V_{\text {crit }}$. Thus, measures to limit wind-driven resuspension are likely to be more effective in Lake Loosdrecht than in lakes Reeuwijk and Nieuwkoop.

Measures to reduce wind-driven resuspension were therefore only further investigated for Lake

Table 5 Wind-wave erosion reducing options for Lake Loosdrecht indicated the percentage of time that the flow velocities at which the critical shear stresses $\left(V_{\text {crit }}\right)$ is exceeded

\begin{tabular}{ll}
\hline Wave reduction options Loosdrecht & $\begin{array}{l}V_{\text {crit }} \\
\text { exceeded (\%) }\end{array}$ \\
\hline $\begin{array}{l}\text { Reference (current situation) } \\
\text { Light option (wave reduction barriers in only }\end{array}$ & 6.04 \\
$\quad$ the most prone positions to erosion) & \\
$\begin{array}{l}\text { Heavy option (wave reduction barriers in all } \\
\text { needed positions) }\end{array}$ & 1.05 \\
$\begin{array}{l}\text { Adapted light option (wave reduction barriers } \\
\text { in most prone positions taking recreational }\end{array}$ & 2.07 \\
$\quad \begin{array}{l}\text { use into account) } \\
\text { Reference }+15 \text { cm water level fluctuation } \\
\quad \text { winter }\end{array}$ & 4.75 \\
$\begin{array}{l}\text { Light option }+15 \text { cm water level fluctuation } \\
\quad \text { inter }\end{array}$ & 2.79 \\
$\begin{array}{l}\text { Light option }+ \text { capping } \\
\text { Light option }+ \text { capping }+15 \text { cm water level } \\
\quad \text { fluctuation winter }\end{array}$ & 2.10
\end{tabular}

Note: $6 \%$ is 21 days per year. The spatial design of these options is shown in Fig. 7
Loosdrecht (Table 5; Fig. 7). They include the construction of wind reducing barriers; both a 'light' option and a 'heavy' option (resp. Fig. 7b, c). In the 'light' option we computed the effect of fetch reduction by implementing a limited number of barriers (sand dikes) in the model calculations; in the 'heavy' option we calculated the effect of fetch reduction by implementing barriers to reduce the $\%$ exceedance as much as possible. For the light option, we strived to minimize the impact on the open water and only reduce the most significant hotspots of erosive activity. This results in reduction of exceedance, from $6.0 \%$, to $3.7 \%$. In the heavy option, barriers were assigned to all areas of hotspots, reducing the exceedance from 6.0 to $1 \%$. After this, for a modified 'light' option we took into account the interests of the recreational sailing community resulting in $2 \%$ exceedance. Additional calculations were done combining the original light option with $15 \mathrm{~cm}$ of water level increase in winter time. Compared to only water level fluctuation ( $4.75 \%$ exceedance) this combination of the light option and water level fluctuations reduces the exceedance to $2.8 \%$. The $15-\mathrm{cm}$ water level fluctuation is an increase in water level, or a 'top-up' using the winter rainfall surplus to an additional $15 \mathrm{~cm}$ of water. This increase in water level not only reduces the need for supplementary water supply to the lakes in summer but also reduced the external nutrient loading that comes with it. However, 15-cm increase in depth, also implies an increase in $k z$, which will have a negative impact on the potential for macrophyte germination in the spring time. Capping of the lake sediment with a layer of medium sized sand, estimated to be ca. $30 \mathrm{~cm}$ thick was added to the model in hotspot areas located in openings (gaps) in the wave reducing barriers that allow boats to pass through (Fig. 7d). In these openings currents are strong due to wind setup and the sand capping allows boating to remain possible. The sand is less prone to erosion and therefore the capping prevents further erosion of the underlying peat layers in these areas $(2.8 \%$ exceedance). Last, the best way of reducing wind-driven resuspension is to implement the heavy option for wave reducing barriers in which barriers are placed in all parts of the lake where resuspension occurs (Fig. 7c). However, the light option, i.e., barriers only in the most affected areas, in combination with sand capping is a more feasible option from practical and societal view points. 

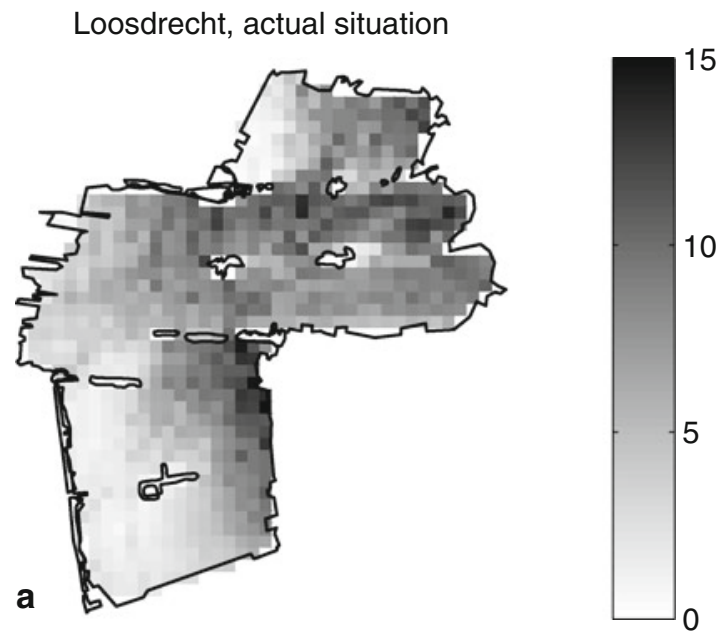

\section{Loosdrecht, heavy variant}

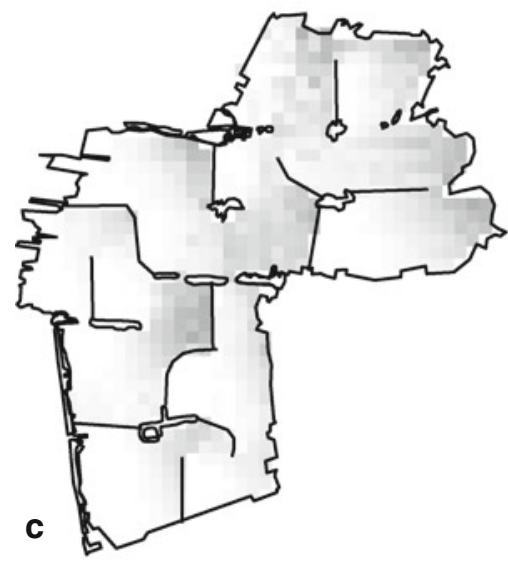

15
Loosdrecht, light variant
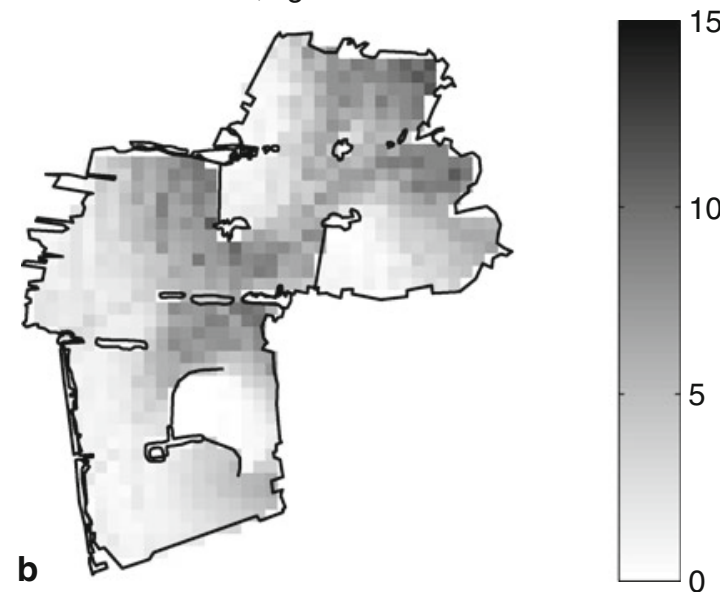

10 0

Loosdrecht, light variant and capping with sand
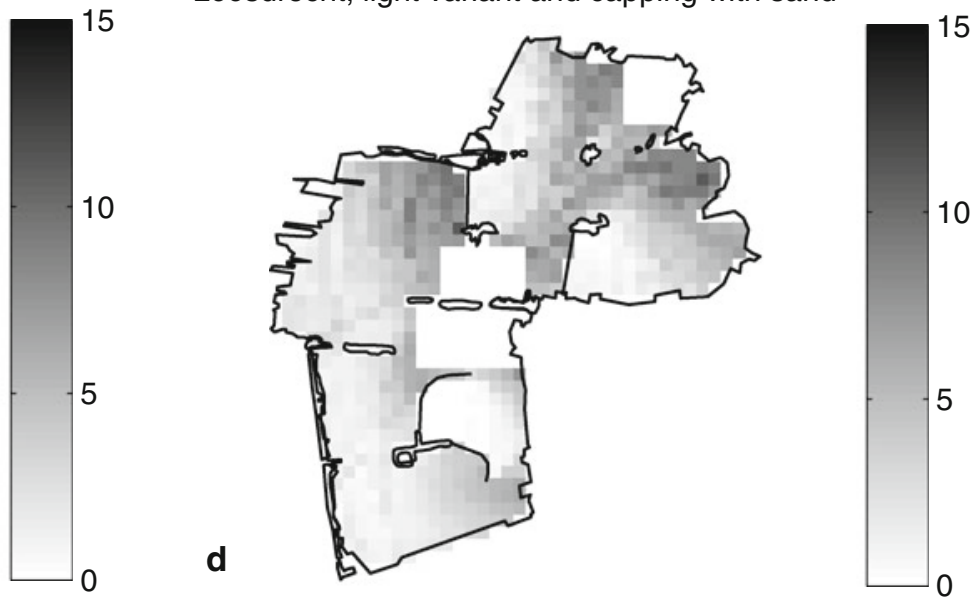

10

Loosdrecht. b Option of implementing 'light' version of wind reducing barriers. c Option of implementing 'heavy' version of wind reducing barriers. d Option of implementing 'light' version of wind reducing barriers and capping with sand in remaining hotspots

sensible to implement wind-wave reducing barriers to improve the overall light climate, for the other two lakes this does not seem to be the most useful approach.

Effectiveness of wind-wave reducing measures

Although the three studied lakes, Loosdrecht, Nieuwkoop, and Reeuwijk, fall within the same WFD lake type (STOWA, 2007), the characteristics of their suspended sediments, their sediment consolidation and depth vary to the extent that the selection of potential measures to reduce resuspension need to take these characteristics in to account. The spatial modeling analyses show that whereas for Loosdrecht is it
In this study we show how to use the results of our measurements to select the most suitable measures (chemical vs. mechanical pathway) to improve transparency in three shallow lakes. For Lake Loosdrecht we further quantified the potential effect of wind-wave reducing measures on the amount of time $V_{\text {crit }}$ was 
exceeded. These measures were the implementation of wave reducing barriers, the raising of the water level in winter and spring time and the partial capping of the sediment with sand. The spatial modeling analyses of these measures showed that although all studied measures seem feasible or successful for reducing wind-driven wave erosion. However, some measures had negative side-aspects: for instance, the "heavy option" of wave reducing barriers is perceived as undesirable from socio-economic and recreation view points and the $15-\mathrm{cm}$ increase in water level in winterspring time negatively affects the percentage light reaching the bottom in spring time, which in turn adversely affects the macrophyte development. Moreover, quantifying the likely benefit of the $15-\mathrm{cm}$ water level increase in reducing nutrient availability for algae growth requires detailed analyses of nutrient cycling in Lake Loosdrecht in relation to primary production over the years. This means less external nutrient loading through retention of rainwater surplus in winter time that might reduce the overall biomass of algae or alter the algae community composition and therefore affect light conditions in the lake.

\section{Sediment characteristics}

The strong resistance in Lake Nieuwkoop of the bottom sediment to erosion and resuspension follows our general understanding of soil consolidation over time: i.e., the longer the period that soil is undisturbed from external disturbance, the more it consolidates to form a stronger matrix (Lambe \& Whitman, 1979; Winterwerp \& Van Kesteren, 2004). For peat soils, a consolidation of the sediment where $V_{\text {crit }}$ becomes significantly stronger needs a 20 - to 40-day disturbance-free period (unpublished data on Lake Loosdrecht sediment, Penning \& Cornelisse, 2006). Foraging activity of benthivorous fish, especially in spring and summer time, can be an additional cause of the disturbance of the sediment (Breukelaar et al., 1994). The loosened bottom matrix then becomes more prone to suspension in the overlying water column by winddriven wave action (Scheffer et al., 2003). Also, the heavy motorized boating traffic might contribute (mainly on good weather, summer days) to the disturbance and suspension of the sediment (pers. obs. M. Genseberger, Deltares).

It remains unknown why in Lake Reeuwijk such small-sized suspended material dominates and why this lake differs from Lake Loosdrecht and Lake Nieuwkoop. Previous changes in water chemistry (due to changes in management of in- and outflows) might have contributed to eutrophication caused by autochthonous material and peat decomposition within the lake (Smolders et al., 2006) but data to confirm this assumption are not available. Also, the fish community in the lake might contribute to the resuspension flux given that it consists of predominantly of benthivorous fish $\left(\sim 150 \mathrm{~kg} \mathrm{ha}^{-1}\right.$, unpublished data Rijnland Waterboard). In an adjacent smaller, more isolated section of the greater Reeuwijk area, a biomanipulation exercise proved to be effective. The large size and the interconnectivity of the currently studied area of the lake make biomanipulation in all probability a temporary treatment because benthivorous fish stock is expected to replenish in a relatively short period, which is comparable to the results reported for other Dutch shallow waters bodies as well as in many European lakes (Gulati \& Van Donk, 2002; Søndergaard et al., 2007). In Lake Nieuwkoop and Lake Loosdrecht, biomanipulation will also be difficult and most likely a temporary shock-treatment, in view of the interconnectivity of the lakes with the surrounding water systems, to which waters the fish escape while being captured for their mass removal (Van Donk et al., 1990).

\section{Spatial modeling analyses}

For the spatial modeling analyses we assumed a single $V_{\text {crit }}$ value per lake for the entire lake bed, based on the averaged critical value of shear stress on the sediment cores. In large, shallow lakes spatial diversity in sediment cohesion depends on prevailing winds, such that the relatively soft and uncompacted sediment (high content of water and organic material) is gathered in relatively sheltered or deeper areas (Zhu, 2008). Lövstedt \& Bengtsson (2008) showed that in Lake Krankesjön (Sweden) winds, particularly from the nonprevailing wind directions, have a strong effect on the amount of resuspended sediment and its redistribution, because most easily eroded material is deposited in the normally sheltered areas that are than affected by these non-prevailing winds. As a result our study might underestimate the contribution of non-prevailing winds to the potential resuspension of material.

For Lake Loosdrecht we did not link the results of the spatial analyses to reduce $V_{\text {crit }}$ exceedance directly 
to change in light climate, nor to macrophyte establishment potential. To do this an annual balance for suspended sediment must be made (Penning et al., 2010) and linked to developments in algae production, which can be affected by altered light conditions (Rijkeboer \& Gons, 1990; Gons \& Rijkeboer, 1990).

Light attenuation in relation to depth

Based on values of light attenuation alone, Lake Nieuwkoop appears to have the best underwater light climate, but if depth $(z)$ is combined with the light attenuation $(k)$, the $k z$ value in this lake is significantly higher than that of Lake Loosdrecht. Consequently, we venture to surmise that Lake Loosdrecht is a more plausible candidate for reestablishment of macrophytes. There are suggestions to create shallower areas in this lake where $k z$ will be $<3.2$, following general studies by Janse et al. (2008) and Johnson et al. (2007). However, care must be taken, because shallower sections are potentially more vulnerable to wind- and wave induced erosion. Lowering the water table is not possible in this peat area as it might affect constructions along the lake and reduce the groundwater table in adjacent peat lands where drained soil oxidation could become a problem when this is done for a longer period. Creating shallow zones by adding sand is also likely to alter the lakes' characteristics, i.e., change the peat bottom to sand-bottomed lakes.

Humic acids are a significant contributor to the total light attenuation in all three lakes $\left(0.5-1.1 \mathrm{~m}^{-1}\right)$ given presence of peat soil in the area (Laanen, 2007). This implies that in order to reach a $k z$ of 3.2 significant efforts are needed to reduce the other contributing substances, both organic suspended matter and algae.

Macrophytes need a minimum amount of light to germinate. This ranges between 0.5 and $35 \%$ of the incoming light at the surface (Dobberfuhl, 2007), depending amongst others on plant species and temperature (Van den Berg et al., 1998), salinity (Dobberfuhl, 2007), sediment type and wave exposure (Istvánovics et al., 2008), cover of sediment with new muddy depositions (Frankland et al., 1987; Dugdale et al., 2001) and seed bank density (Van den Berg, 2001). Freshwater plant communities in Lake Balaton are found in situations where light at the bed is $2-3 \%$ (Istvánovics et al., 2008) and Dobberfuhl (2007) reports $9 \%$ for low salinity sites $(<0.5 \mathrm{ppt})$ and $14 \%$ for high salinity sites $(>0.5 \mathrm{ppt})$ in St. Johns River
(Florida). Experiments on charids by Küster et al. (2004) show minimal light conditions of $35 \mu \mathrm{mol}$ photons $\mathrm{m}^{-2} \mathrm{~s}^{-1}$ is needed for growth. Similar values are reported by De Winton et al. (2004) for charids and by Van den Berg et al. (1998) for Chara aspera and Potamogeton pectinatus. The growth of macrophytes is less under such low light dosages than at higher light dosages (10\% of max). Using a daily photon flux of approximately $800 \mu \mathrm{mol}$ photons $\mathrm{m}^{-2} \mathrm{~s}^{-1}$ (Grant \& Slusser, 2004; Istvánovics et al., 2008) the $35 \mu \mathrm{mol}$ photons $\mathrm{m}^{-2} \mathrm{~s}^{-1}$ is comparable to a $4 \%$ light availability as an average value. Since light intensity varies during the day and growing season, we choose this approximation of $4 \%$ light reaching the bottom rather than a true value of $\mu \mathrm{mol}$ photons $\mathrm{m}^{-2} \mathrm{~s}^{-1}$ that is often mentioned as the light compensation point for photosynthesis in lab experiments.

Other examples of wind reducing measures

To our knowledge there is only one recorded case of a lake where large scale wind reducing measures have already been implemented and evaluated for reducing turbidity to facilitate the return of macrophyte communities: Huang \& Liu (2009) described the effects of a 3.3-km-long wave barrier implemented in Lake Taihu on sediment resuspension inside and outside the protected area. They showed that the barrier reduced sediment resuspension to less than $37 \%$ of the nonprotected zone. Given the high trophic status of Lake Taihu the reduction did not result in macrophyte development, but rather enhanced phytoplankton production. If nutrient loads are high, the improved light conditions due to reduced suspended sediments might favor quickly developing phytoplankton over macrophyte establishment, and wave reducing barriers should therefore be implemented only when nutrient loads are sufficiently low. In some larger turbid lakes in the Netherlands such as Lake Markermeer similar (desktop) studies to reduce wind-driven wave action and manage resuspension have been undertaken very recently (Boderie \& Hulsbergen 2009; Vijverberg et al., 2010; Genseberger et al., 2011). Also, small scale barriers have been implemented Lake Markermeer to reduce wave and ice action on an important dyke in this lake, for which unfortunately only ad-hoc data on water quality are available, that do not allow for appropriate evaluation of the functioning of the barriers in limiting resuspension of sediments 
(RWS-RIZA, 2007). For the shallow lake Apopka (Florida USA) similar suggestions have been made to implement wave reducing barrier in order to reduce resuspension of weak organic sediments (Bachmann et al., 1999). Gulati et al. (2008) also advocate the use of new ecotechnological approaches to improve ecological status of wind-exposed, shallow lakes, in addition to the more primary control measures as nutrient load reduction. The lack of sufficient examples where measures involving reduction of wind effects have been carried out and evaluated has intensified the debate on whether or not resuspension of suspended matter through wind action prevents lake recovery (Bachmann et al., 1999, 2001; 2005; Lowe et al., 2001; Jeppesen et al., 2003; Schelske et al., 2010). This study contributes to the notion that for shallow lakes where wind-wave action plays a role in resuspension of sediments the answer towards the best management options for improvements of ecological status lies probably in a combination of measures from different pathways. Both nutrient loading and winddriven resuspension should both be quantified correctly, taking into account also the effects of the fish community present in the lake on both internal eutrophication and sediment cohesion and resuspension potential.

\section{Conclusion}

We used the combined light attenuation coefficient $k$ with the water depth $d$ as a proxy for indicating the status of the light climate in three large shallow peat lakes. This gives a better idea of the potential for macrophyte germination, assuming that a given percentage of light at the bottom is needed, rather than only looking at the light attenuation coefficient as such.

We assessed the main contributors to the overall light attenuation and found that the suspended organic sediment in all the three studied lakes is most important. We therefore further characterized the suspended sediment by linking its dry weight to size specific light attenuation and measured light attenuation during laboratory experiments. This showed that suspended matter in Lake Reeuwijk is relatively small and contributes more to the light attenuation than that of Lake Nieuwkoop and Lake Loosdrecht. Sediment in Lake Nieuwkoop is less prone to resuspension as it is more consolidated, probably because of its less frequent disturbance by wind-driven wave action. In Lake Loosdrecht the potential for wind-driven resuspension is most marked, given its shallower depth and higher fetch of the lake in comparison to the other two studied lakes. In this lake measures to reduce fetch and wave action on the sediment by wave barriers, sand capping and increasing the water level reduce the percentage exceedance of the critical shear stress threshold. Discussions with stakeholders on selecting the most appropriate set of measures to reduce windinduced wave action in this lake showed that next to technical result also socio-economic and water quality effects of the measures need to be taken into account.

Acknowledgments We would like to thank Marcel Busink, Marcel Grootteboer, Saskia Huisman, and Kees Korree from Deltares for their valuable assistance with the field and laboratory analyses. This study has been financed by the regional waterboards Rijnland and Waternet. We thank Bruce Michielsen (Waterboard Rijnland) and Maarten Ouboter (Waterboard Waternet) for their valuable contributions during discussions and their assistance in supplying monitoring data. We thank Ramesh Gulati (NIOO-KNAW) and two anonymous reviewers who contributed greatly to the improvement of an earlier draft of this manuscript. This is NIOO publication number 5217.

Open Access This article is distributed under the terms of the Creative Commons Attribution License which permits any use, distribution, and reproduction in any medium, provided the original author(s) and the source are credited.

\section{References}

Bachmann, R. W., M. V. Hoyer \& D. E. Canfield Jr., 1999. The restoration of Lake Apopka in relation to alternative stable states. Hydrobiologia 394: 219-232.

Bachmann, R. W., M. V. Hoyer \& D. E. Canfield, 2001. Evaluation of recent limnological changes at Lake Apopka. Hydrobiologia 448: 19-26.

Bachmann, R. W., M. V. Hoyer, S. Vinzon \& D. E. Canfield, 2005. The origin of the fluid mud layer in Lake Apopka, Florida. Limnology and Oceanography 50: 629-635.

Bakker, P. A., C. A. J. Van der Hoeven-Loos, L. R. Mur \& A. Stork, 1976. De Noordelijke Vechtplassen. Flora en fauna (The Northern Vecht Lakes. Flora and fauna). Stichting Commissie voor de Vecht en het oostelijk en Westelijk Plassengebied: 393 pp (in Dutch).

Best, E. P. H., D. De Vries \& A. Reins, 1984. The macrophytes in the Loosdrecht Lakes: A story of their decline in the course of eutrophication. Verhandlungen des Internationalen Verein Limnologie 22: 868-875.

Best, E. P. H., A. M. Teeter, K. J. Landwehr, W. G. James \& S. K. Nair, 2008. Restoration options for potential persistence 
of submersed aquatic vegetation: Combining ecological, hydrodynamic and sediment transport modeling. Freshwater Biology 53: 814-826.

Boderie, P. M. A. \& R. P. Hulsbergen, 2009. Model study silt measures Lake Eem. Technical report Q4524, Deltares, The Netherlands (in Dutch).

Breukelaar, A. W., E. H. R. R. Lammens, J. P. G. Klein Breteler \& I. Tatrai, 1994. Effects of benthivorous bream (Abramis brama L.) and carp (Cyprinus caprio L.) on sediment resuspension and concentration of nutrients and chlorophyll $a$. Freshwater Biology 32: 113-121.

Brönmark, C. \& L. A. Hansson, 2002. Environmental issues in lakes and ponds: current state and perspectives. Environmental Conservation 29: 290-307.

Buiteveld, H., 1995. A model for calculation of diffuse light attenuation (PAR) and Secchi depth. Netherlands Journal of Aquatic Ecology 29: 55-65.

Cornelisse, J. M., C. Kuijper \& J. C. Winterwerp, 1993. Evaluatie in situ erosiemeters (Evaluation of in-situ erosion meters). WL/Deltares report Z161/31, Delft, The Netherlands (in Dutch).

De Winton, M. D., M. T. Casanova \& J. S. Clayton, 2004. Charophyte germination and establishment under low irradiance. Aquatic Botany 79: 175-187.

Dobberfuhl, D. R., 2007. Light limiting thresholds for submerged aquatic vegetation in a blackwater river. Aquatic Botany 86: 346-352.

Dugdale, T. M., M. D. De Winton \& J. S. Clayton, 2001. Burial limits to the emergence of aquatic plant propagules. New Zealand Journal of Marine and Freshwater Research 35: 147-153.

European Union, 2000. Directive 2000/60/EC of the European Parliament and of the Council of 23 October 2000 establishing a framework for Communities in the field of water policy, Official Journal of the European Communities, L 327/1, 22/12/2000.

Frankland, B., M. R. Bartley \& D. H. N. Spence, 1987. Germination under water. In Crawford, R. M. M. (ed.), Plant Life in Aquatic and Amphibious Habitats. Blackwell Scientific Publishing, Oxford: 167-177.

Genseberger, M., P. M. A. Boderie \& M. Van der Wal, 2011. Fetch length reduction as an effective and multipurpose measure for shallow lakes. Poster presented at the 7 th International Shallow Lake Conference, April 24-28 2011, Wuxi, China.

Gons, H. J. \& M. Rijkeboer, 1990. Algal growth and loss rates in Lake Loosdrecht: First evaluation of the roles of light and wind on a basis of steady state kinetics. Hydrobiologia 191: 129-138.

Gons, H. J., R. Veeningen \& R. Van Keulen, 1986. Effects of wind on a shallow lake ecosystem: resuspension of particles in the Loosdrecht Lakes. Hydrobiological Bulletin 20: 109-120.

Grant, R. H. \& J. R. Slusser, 2004. Estimation of photosynthetic photon flux density from $368-\mathrm{nm}$ spectral irradiance. Journal of Atmospheric and Oceanic Technology 21: 481-487.

Gulati, R. D. \& E. Van Donk, 2002. Lakes in the Netherlands, their origin, eutrophication and restoration: State-of-the-art review. Hydrobiologia 478: 73-106.
Gulati, R. D., L. M. Dionisio Pires \& E. Van Donk, 2008. Lake restoration studies: Failures, bottlenecks and prospects of new ecotechnological measures. Limnologica 38: 233-247.

Huang, P. S. \& Z. W. Liu, 2009. The effect of wave-reduction engineering on sediment resuspension in a large, shallow, eutrophic lake (Lake Taihu). Ecological Engineering 35: 1619-1623.

Hurdle, D. P. \& R. J. H. Stive, 1989. Revision of SPM 1984 wave hindcast model to avoid inconsistencies in engineering applications. Coastal Engineering 12: 339-351.

Istvánovics, V., M. Honti, A. Kovács \& A. Osztoics, 2008. Distribution of submerged macrophytes along environmental gradients in large, shallow Lake Balaton (Hungary). Aquatic Botany 88: 317-330.

James, W. F. \& J. W. Barko, 1994. Macrophyte influences on sediment resuspension and export in a shallow impoundment. Lake and Reservoir Management 10: 95-102.

James, W. F., E. P. H. Best \& J. W. Barko, 2004. Sediment resuspension and light attenuation in Peoria Lake: Can macrophytes improve water quality in this shallow system? Hydrobiologia 515: 193-201.

Janse, J. H., L. N. De Senerpont Domis, M. Scheffer, L. Lijklema, L. Van Liere, M. Klinge \& W. M. Mooij, 2008. Critical phosphorous loading of different types of shallow lakes and the consequences for management estimated with the ecosystem model PC Lake. Limnologica 38: 203-219.

Jeppesen, E., J. P. Jensen, M. Søndergaard, K. S. Hansen, P. H. Møller, H. U. Rasmusen, V. Norby \& S. E. Larsen, 2003. Does resuspension prevent a shift to a clear state in shallow lakes during reoligotrophication? Limnology and Oceanography 48: 1913-1919.

Jeppesen, E., M. Meerhoff, B. A. Jacobsen, R. S. Hansen, M. Søndergaard, J. P. Jensen, T. L. Lauridsen, N. Mazzeo \& C. W. C. Branco, 2007. Restoration of shallow lakes by nutrient control and biomanipulation-The successful strategy varies with lake size and climate. Hydrobiologia 581: 269-285.

Johnson, K. G., M. S. Allen \& K. E. Havens, 2007. A review of littoral vegetation, fisheries, and wildlife responses to hydrologic variation at Lake Okeechobee. Wetlands 27: 110-126.

Kemp, W. M., R. Batiuk, R. Bartleson, P. Bergstrom, V. Carter, C. L. Gallegos, W. Hunley, L. Karrh, E. W. Koch, M. M. Landwehr, K. A. Moore, L. Murray, M. Naylor, B. Rybicki, J. C. Stevenson \& D. J. Wilcox, 2004. Habitat requirements for submerged aquatic vegetation in Chesapeake Bay: Water quality, light regime, and physicalchemical factors. Estuaries 27: 363-377.

Kenworthy, W. J. \& M. S. Fonseca, 1996. Light requirements of seagrasses Halodule wrightii and Syringodium filiforme derived from the relationship between diffuse light attenuation and maximum depth distribution. Estuaries 19: 740-750.

Küster, A., R. Schaible \& H. Schubert, 2004. Light acclimation of photosynthesis in three charophyte species. Aquatic Botany 79: 111-124.

Laanen, M., 2007. Yellow matters. Improving the Remote Sensing of Coloured Dissolved Organic Matter in Inland 
Freshwaters. PhD thesis, Vrije Universiteit Amsterdam, The Netherlands.

Lambe, T. W. \& R. V. Whitman, 1979. Soil Mechanics SI Version. John Wiley \& Sons, New York, $553 \mathrm{pp}$.

Leentvaart, P. \& M. F. Mörzer Bruijns, 1962. De verontreiniging van de Loosdrechtse Plassen en haar gevolgen (The pollution of the Loosdrechtse Plassen and the consequences). De Levende Natuur 65: 42-48 (in Dutch).

Lövstedt, C. B. \& L. Bengtsson, 2008. The role of non-prevailing wind direction on resuspension and redistribution of sediments in a shallow lake. Aquatic Sciences 70: 304-313.

Lowe, E. F., L. E. Battoe, M. F. Coveney, C. L. Schelske, K. E. Havens, E. R. Marzolf \& K. R. Reddy, 2001. The restoration of Lake Apopka in relation to alternative stable states: An alternative view to that of Bachmann et al. (1999). Hydrobiologia 448: 11-18.

Medusa, 2007. Loosdrechtse Plassen (Lake Loosdrecht. Analyses on 3 sediment cores). Analyse van 3 kernen. Medusa rapport, rapp.nr. 2007-185R1 (in Dutch).

Meijer, M. L., I. De Boois, M. Scheffer, R. Portielje \& H. Hosper, 1999. Biomanipulation in shallow lakes in The Netherlands: an evaluation of 18 case studies. Hydrobiologia 408: 13-30.

Moss, B., 1998. Ecology of Fresh Waters. Man and Medium, Past to Future, 3rd ed. Blackwell Science, Oxford, 557 pp.

Nöther, B., 1989. Untersuchungen zum Resuspensionsverhalten von Ästuarschwebstoff (Research on the resuspension behaviour of estuarine suspended matter). GKSS-Forschungszentrum Geesthacht GHBM, GKSS89/E/38 (in German).

Penning, W. E., R. Uittenbogaard, M. Ouboter \& E. Van Donk, 2010. Local deepening of large shallow peat lakes: A measure to improve their ecological status. Journal of Limnology 69: 126-137.

Rijkeboer, M. \& H. J. Gons, 1990. Light-limited algal growth in Lake Loosdrecht: Steady state studies in laboratory scale enclosures. Hydrobiologia 191: 241-248.

RWS-RIZA, 2007. Vooroevers Houtribdijk: toestand ecologie en waterkwaliteit 2006 (Shore protecting barriers along the Houtribdijk: ecological status and water quality 2006). RWS-RIZA report 2007.006, Lelystad, The Netherlands (in Dutch).

Scheffer, M., 2001. Ecology of Shallow Lakes. Kluwer Academic Publishers, Dordrecht,. 357 pp.

Scheffer, M., R. Portielje \& L. Zambrano, 2003. Fish facilitate wave resuspension of sediment. Limnology and Oceanography 48: 1920-1926.

Schelske, C. L., E. F. Lowe, W. F. Kenney, L. E. Battoe, M. Brenner \& M. R. Coveney, 2010. How anthropogenic darkening of Lake Apopka induced benthic light limitation and forced the shift from macrophyte to phytoplankton dominance. Limnology and Oceanography 55: 1201-1212.

Shields, A., 1936. Application of similarity principles and turbulence research to bed-load movement (Änwendung der Aehnlichkeitsmechanik und der Turbulenszforschung auf die Geschiebe-bewegung. Mitteilung der Preussischen Versuchsanstalt fur Wasserbau und Schiffbau, Berlin) (Trans: W. P. Ott, J. C. van Uchelen). Soil Conservation Service, California Institute of Technology, Pasadena, USA.
Sloot, J., 1995. Resuspension, sedimentation and light climate in the Nieuwkoopse Plassen. Report No 09/95, Wageningen University-Aquatic ecology and water quality management group. MSc Thesis, Supervision by prof. G. Blom (in Dutch).

Smolders, A. J. P., L. P. M. Lamers, E. C. H. E. T. Lucassen, G. Van der Velde \& J. G. M. Roelofs, 2006. Internal eutrophication: How it works and what to do about it - a review. Chemistry and Ecology 22(2): 93-111.

Sollie, S., H. Coops \& J. T. A. Verhoeven, 2008. Natural and constructed littoral zones as nutrient traps in eutrophicated shallow lakes. Hydrobiologia 605: 219-233.

Søndergaard, M., E. Jeppesen, T. L. Laurdsen, C. Skov, E. H. Van Nes, R. Roijackers, E. Lammens \& R. Portielje, 2007. Lake restoration: Successes, failures and long-term effects. Journal of Applied Ecology 44: 1095-1105.

STOWA, 2007. Referenties en maatlatten voor natuurlijke watertypen voor de kaderrichtlijn water (References and status definitions for natural water types for the Water Framework Directive). STOWA rapportnummer 2007-32, Utrecht, The Netherlands (in Dutch).

Van Dam, H. \& L. J. Frinking, 1997. Effects of eutrophication reduction on epiphytic diatom assemblages in the Nieuwkoop lakes, The Netherlands. Phycologia 36(4): 114-115 (Abstracts Sixth International Phycological Congress, Leiden 9-16 August 1997).

Van Dam, H. \& A. Mertens, 1993. Diatoms on herbarium macrophytes as indicators for water quality. Hydrobiologia 269/270: 437-445.

Van den Berg, M. S., 2001. Propagule bank buildup of Chara aspera and its significance for colonization of a shallow lake. Hydrobiologia 462(1-3): 9-17.

Van den Berg, M. S., H. Coops, J. Simons \& A. De Keizer, 1998. Competition between Chara aspera and Potamogeton pectinatus as a function of temperature and light. Aquatic Botany 60: 241-250.

Van den Berg, M. S. \& G. Delaunay, unpublished. The relationship between light, submerged macrophytes and propagule bank in shallow lakes.

Van der Does, J., P. Verstraelen, P. Boers, J. Van Roestel, R. Roijackers \& G. Moser, 1992. Lake restoration with and without dredging of phosphorus-enriched upper sediment layers. Hydrobiologia 233: 197-210.

Van Donk, E., M. P. Grimm, R. D. Gulati, P. G. M. Heuts, W. A. de Kloet \& L. van Liere, 1990. First attempt to apply whole-lake food-web manipulation on a large scale in the Netherlands. Hydrobiologia 200(201): 291-301.

Van Duin, E. H. S., G. Blom, F. J. Los, R. Maffione, R. Zimmerman, C. F. Cerco, M. Dortch \& E. P. H. Best, 2001. Modeling underwater light climate in relation to sedimentation, resuspension, water quality and autotrophic growth. Hydrobiologia 444: 25-42.

Van Geest, G. J., H. Coops, R. M. M. Roijackers, A. D. Buijse \& M. Scheffer, 2005. Succession of aquatic vegetation driven by reduced water-level fluctuations in floodplain lakes. Journal of Applied Ecology 42(2): 251-260.

Van Liere, L., 1986. Loosdrecht Lakes, origin, eutrophication, restoration and research programme. Hydrobiological Bulletin 20: 101-107.

Vijverberg, T., J. C. Winterwerp, S. G. J. Aarninkhof \& H. Drost, 2010. Fine sediment dynamics in a shallow lake and 
implication for design of hydraulic Works. Ocean Dynamics. doi:10.1007/s10236-010-0322-2.

Winterwerp, J. C. \& W. G. M. Van Kesteren, 2004. Introduction to the Physics of Cohesive Sediments in the Marine Environment. Elsevier, Amsterdam, 466 pp.

WL/Deltares, 2001. User manual OSLIM/FOSLIM. WL/Delft Hydraulics/Deltares instrumentation report, Delft, The Netherlands.
Zhu, G. W., 2008. Sediment-water exchange and its significance. In Qin, B. Q. (ed.), Lake Taihu, China. Dynamics and Environmental Change. Monographiae Biologicae 87. Springer, Dordrecht: 151-158, 339 pp. 